\title{
BEHAVIOR OF FULLY ENCASED STEEL-CONCRETE COMPOSITE COLUMNS SUBJECTED TO MONOTONIC AND CYCLIC LOADING
}

\author{
Dr Cristina Campian* \\ Technical University of Cluj, Belgrade, Cluj-Napoca, Romania \\ Alina Haupt-Karp \\ Technical University of Cluj, Belgrade, Cluj-Napoca, Romania \\ Maria Pop \\ Technical University of Cluj, Belgrade, Cluj-Napoca, Romania \\ Dr Nicolae Chira \\ Technical University of Cluj, Belgrade, Cluj-Napoca, Romania \\ Gabriel Urian \\ Technical University of Cluj, Belgrade, Cluj-Napoca, Romania \\ Dr Paul Pernes \\ Technical University of Cluj, Belgrade, Cluj-Napoca, Romania
}

The paper presents a numerical model developed for fully encased steel-concrete composite columns under monotonic and cyclic loading. The numerical model was realized with the FineLg program, developed at ArGenCo department, University of Liège. The numerical model was validated using five experimental tests taken from the international literature: two realised at Technical University of Cluj-Napoca and the others in Taiwan, USA and China. The experimental tests used for validation of the numerical model dealt with both normal and high strength concrete. Different parameters were compared in the paper: partial and full ductility, energy dissipation, resistance and rigidity ratio.

Key words: Fully encased composite columns, Numerical model

\section{INTRODUCTION}

Aside the experimental research on fully encased steel-concrete composite columns, another very important side is the analytical research, the mathematical modeling of the member behavior, under monotonic and cyclic loading. Computer simulation of the behavior of elements is a much cheaper, rapid and efficient method of research, but it cannot exclude and reduce the importance of experimental research. The calibration of proposed numerical model was based on five experimental programs taken from the international literature.

\section{EXPERIMENTAL PROGRAMS USED FOR VALIDATION OF THE NUMERICAL MODEL}

The first two experimental programs used for validation were developed in the Structures Department, at Faculty of Civil Engineering, Technical University of Cluj-Napoca, Romania, year 2000 and 2011.The third program was developed at National Central University in Taiwan, year 2008. The forth experimental research was developed at California University in San Diego, USA in 1992 and the fifth at Chiao Tung University, Hsinchu, China, in 2008. The first four experimental programs used I type steel profiles and the last used cross steel profiles fully embedded in concrete. All columns were subjected to compressive axial loading and bending moment (induced by horizontal lateral forces), except the fourth program where the columns were additionally subjected to shear too. The mechanical model and test up procedure for all experimental programs are presented in Figure 1.

\section{EXPERIMENTAL PROGRAM DEVELOPED AT UTC-N, ROMANIA, 2000}

The experimental program realized by Cristina Campian, 2000, at Technical University of ClujNapoca, Romania, included 12 tests (3 mono- 
tonic and 9 cyclic) on fully encased steel-concrete composite columns. All columns had the same cross-section and were grouped according to their length. The elements were made with a Romanian steel section 112 (which is quasi similar to IPE 120 section) fully covered with reinforced concrete including 4 op 10 longitudinal bars as shown in Figure 2. In Table 1 are presented some characteristics of the tested specimens.
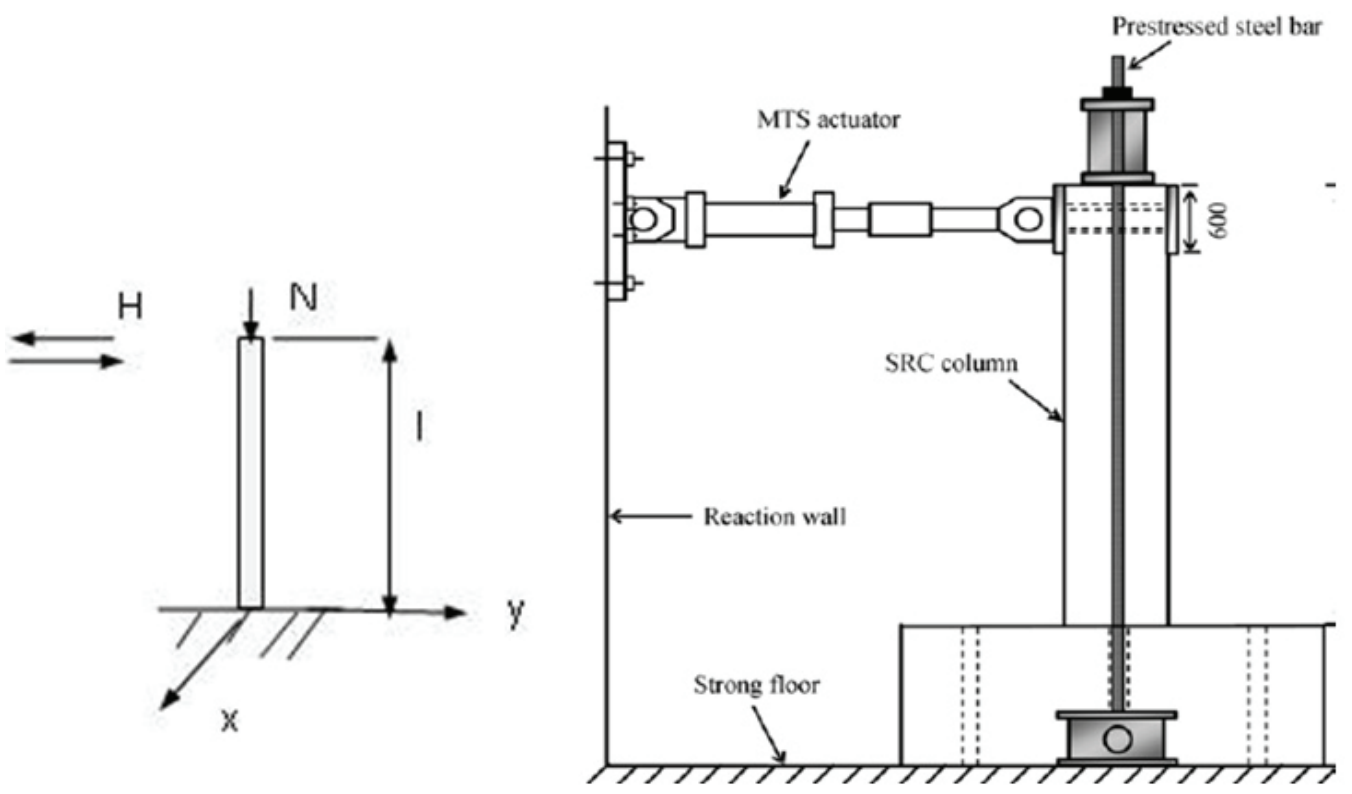

Figure 1: Mechanical model and test up procedure for experimentally tested columns

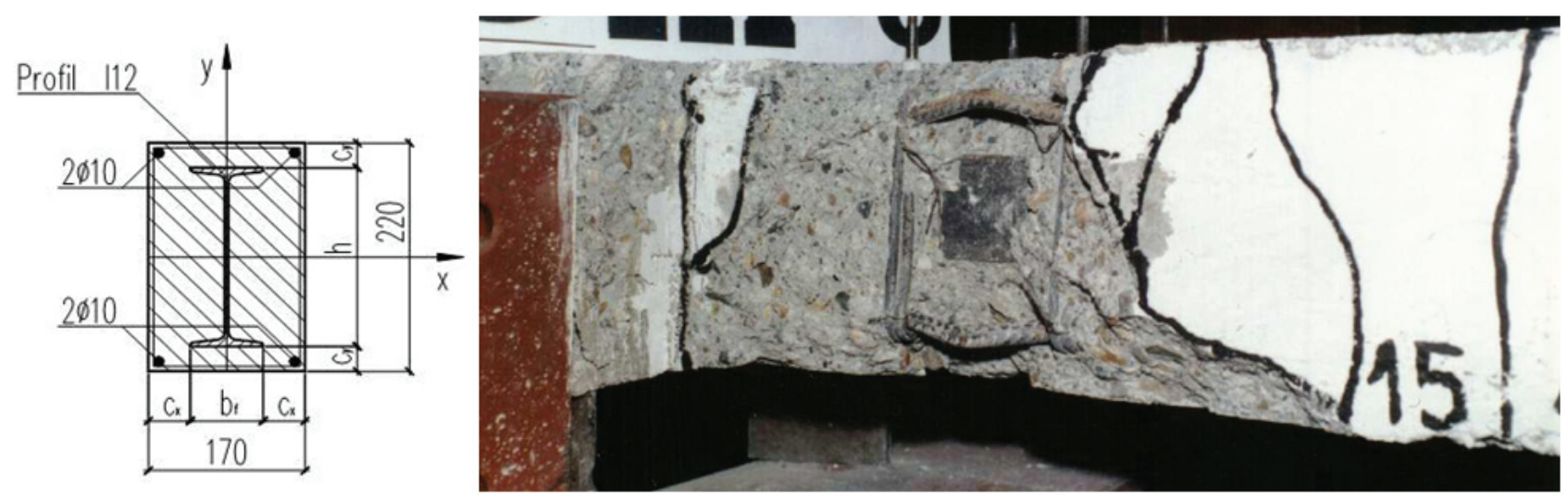

Figure 2: Cross-section of the tested specimens and failure mode

Table 1: Characteristics of tested specimens

\begin{tabular}{|c|c||c|c|c|c|c||c|}
\hline $\begin{array}{c}\text { Column } \\
\text { type }\end{array}$ & $\begin{array}{c}\text { Length } \\
{[\mathrm{m}]}\end{array}$ & $\begin{array}{c}\text { Compressive } \\
\text { concrete strength } \\
{\left[\mathrm{N} / \mathrm{mm}^{2}\right]}\end{array}$ & $\begin{array}{c}\text { Concrete } \\
\text { Young } \\
\text { modulus } \\
{\left[\mathrm{N} / \mathrm{mm}^{2}\right]}\end{array}$ & $\begin{array}{c}\text { Yield strength } \\
\text { of longitudinal } \\
\text { reinforcement } \\
{\left[\mathrm{N} / \mathrm{mm}^{2}\right]}\end{array}$ & $\begin{array}{c}\text { Longitudinal } \\
\text { reinforcement } \\
\text { Young modulus } \\
{\left[\mathrm{N} / \mathrm{mm}^{2}\right]}\end{array}$ & $\begin{array}{c}\text { Yield } \\
\text { strength of } \\
\text { embedded } \\
\text { profile } \\
{\left[\mathrm{N} / \mathrm{mm}^{2}\right]}\end{array}$ & $\begin{array}{c}\text { Embedded } \\
\text { profile Young } \\
\text { modulus } \\
{[\mathrm{N} / \mathrm{mm}]}\end{array}$ \\
\hline \hline SI & 2.00 & 30.5 & - & & & 302 & 207000 \\
\hline SII & 2.50 & 27.0 & - & 559 & 207000 & & \\
\hline SIII & 3.00 & 29.5 & 37373.33 & & & & \\
\hline
\end{tabular}

The failure of all tested columns was governed by the plastic hinge formation at column base (see Figure 2) 


\section{EXPERIMENTAL PROGRAM DEVELOPED AT} UTC-N, ROMANIA, 2011

The two types of composite columns tested by Vlădut Sav, 2011, were similar to the ones tested at Technical University of Cluj-Napoca in 2000. The main difference between the experimental programs was the type of concrete used. The author of the experimental program use high strength concrete, class $\mathrm{C70/85}$. The tested columns had 2 different lengths: $3.00 \mathrm{~m}$ (columns $\mathrm{S} 1, \mathrm{~S} 2, \mathrm{~S} 3$ and S4) and $2.00 \mathrm{~m}$ (columns S5, S6, S7 and S8). The cross-section of the composite column was the same for all tested specimens, of $170 \times 220 \mathrm{~mm}$ (see figure 3), with an IPN120 embedded profile and $4 \varnothing 10$ bars as longitudinal reinforcement.

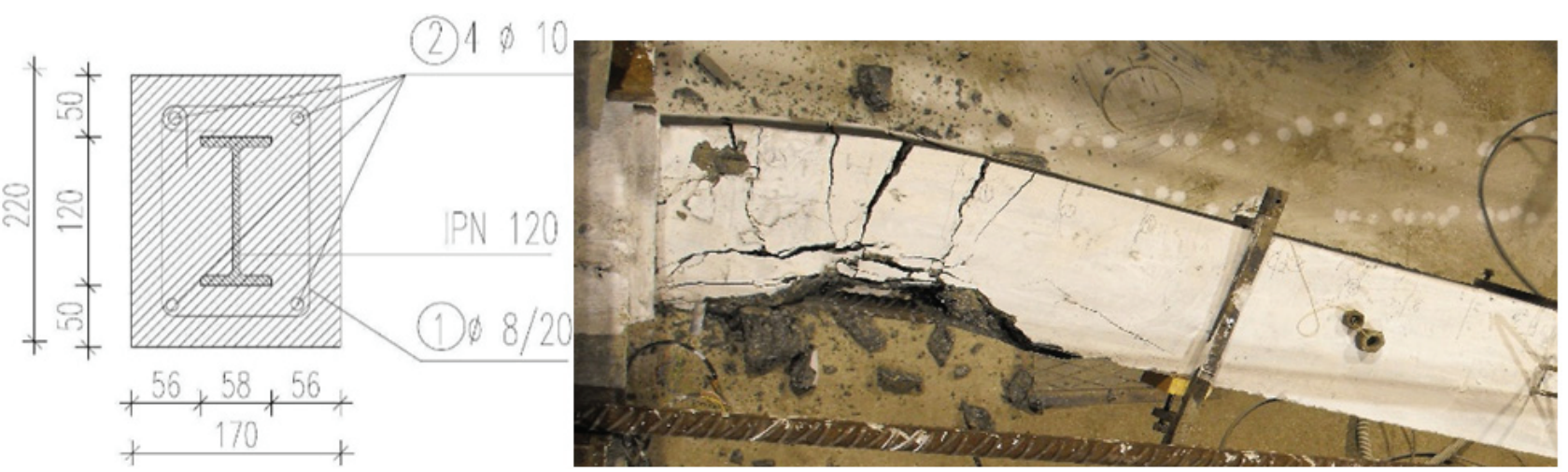

Figure 3: Cross-section of the tested specimens and failure mode

In Table 2 are presented a few characteristics of the tested specimens. The author performed first monotonic tests on both type of columns and after, three cyclic tests for each type of column.

Table 2. Characteristics of tested specimens

\begin{tabular}{|c|c|c|}
\hline $\begin{array}{c}\text { Compressive concrete strength } \\
{\left[\mathrm{N} / \mathrm{mm}^{2}\right]}\end{array}$ & $\begin{array}{c}\text { Concrete Young modulus } \\
{\left[\mathrm{N} / \mathrm{mm}^{2}\right]}\end{array}$ & $\begin{array}{c}\text { Yield strength of steel } \\
{\left[\mathrm{N} / \mathrm{mm}^{2}\right]}\end{array}$ \\
\hline 92,3 & 43634,65 & 380.20 \\
\hline
\end{tabular}

The failure mode was similar for all tested specimens. In comparison with the columns made with normal concrete and presented at 2.1, the failure of the columns made with high strength concrete was violent and brittle.

\section{EXPERIMENTAL PROGRAM DEVELOPED AT NCU, CHUNG-LI, TAIWAN, 2008}

The experimental study made by H. L. Hsu, F. J. Jan and J. L. Juang, 2008, was developed at the Department of Civil Engineering, National Central University, Chung-Li, Taiwan. All tested columns had the same cross-section, $370 \mathrm{~mm} x$ $370 \mathrm{~mm}$ (see Figure 4), with six different embed-
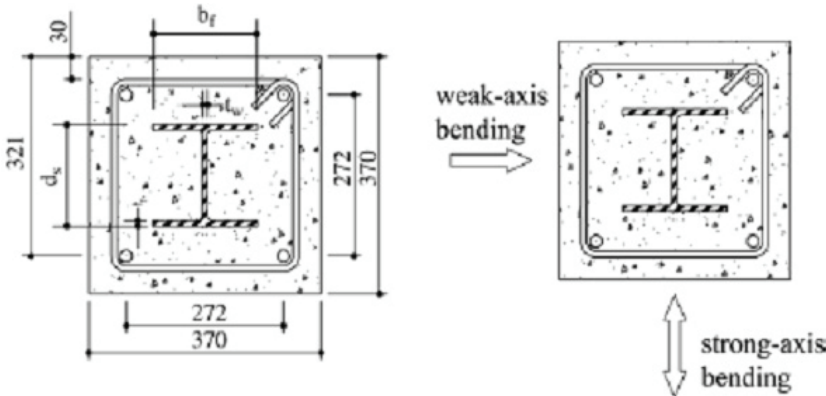

ded profiles (Table 3). The type of loading and direction are presented also in Table 3.

Identical reinforcement were used in all specimens, 4Ф20 as longitudinal reinforcement and $\Phi 9.525$ stirrups. The stirrup spacing was 100 $\mathrm{mm}$ within the confined zones and $150 \mathrm{~mm}$ in the non-confined zones. Yield strength for the structural steel, longitudinal bars and stirrups were $314 \mathrm{MPa}, 543 \mathrm{MPa}$ and $586 \mathrm{MPa}$ respectively. The concrete compressive strength, determined from cylinder tests was $38 \mathrm{MPa}$.

The member performances were governed by plastic hinge formation, as shown in Figure 4.

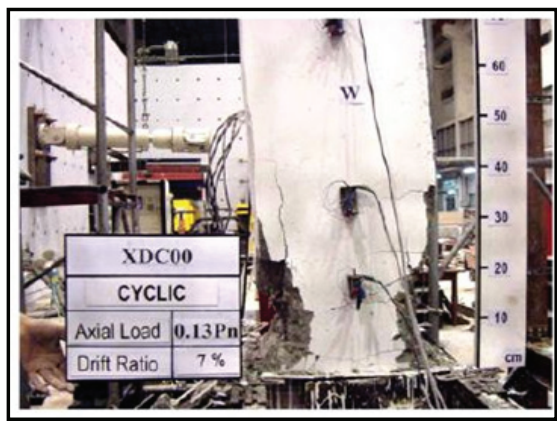

Figure 4: Cross-section of the tested specimens and failure mode 
Table 3: Characteristics of tested specimens

\begin{tabular}{|c|c|c|c|}
\hline Column type & Embedded profile & Loading direction & Loading type \\
\hline YAM & $\mathrm{H} 100 \times 100 \times 6 \times 8$ & & \\
\hline YBM & $\mathrm{H} 150 \times 100 \times 6 \times 9$ & & \\
\hline YDM & $\mathrm{H} 200 \times 100 \times 5.5 \times 8$ & & \\
\hline YCM & $\mathrm{H} 150 \times 150 \times 7 \times 10$ & & \\
\hline YEM & $\mathrm{H} 200 \times 150 \times 6 \times 9$ & & \\
\hline YFM & $\mathrm{H} 200 \times 200 \times 8 \times 12$ & Weak-axis bending & monotonic \\
\hline XAC00 & $\mathrm{H} 100 \times 100 \times 6 \times 8$ & & \\
\hline XBC00 & $\mathrm{H} 150 \times 100 \times 6 \times 9$ & & \\
\hline XDC00 & $\mathrm{H} 200 \times 100 \times 5.5 \times 8$ & & \\
\hline XCCO0 & $\mathrm{H} 150 \times 150 \times 7 \times 10$ & & \\
\hline XECOO & $\mathrm{H} 200 \times 150 \times 6 \times 9$ & \multirow{2}{*}{$\begin{array}{l}\text { Axial loading + strong- } \\
\text { axis bending }\end{array}$} & \\
\hline XFC00 & H200x200x8x12 & & cyclic \\
\hline
\end{tabular}

EXPERIMENTAL PROGRAM DEVELOPED AT UC, SAN DIEGO, CALIFORNIA, SUA, 1992

The experimental program realized by James M. Ricles and Shannon Paboojian, 1992, was performed on fully encased steel-concrete composite columns, subjected to compressive axial load, bending moment and shear. The tests were developed at California University in San Diego, USA. The composite columns analyzed consisted of a W8x40 steel profile encased in a 406x406 $\mathrm{mm}$ reinforced concrete section. The two chosen sections used for validation of the numerical model had the same length, the same embedded profile and the same longitudinal and transversal reinforcement, but different concrete class.

Table 4: Characteristics of tested specimens

\begin{tabular}{|c|c|c||c|c|c|c|}
\hline $\begin{array}{c}\text { Specimen } \\
\text { no. }\end{array}$ & $\mathrm{db}[\mathrm{mm}]$ & $\begin{array}{c}\mathrm{s} \\
{[\mathrm{mm}]}\end{array}$ & $\begin{array}{c}\text { Length } \\
{[\mathrm{mm}]}\end{array}$ & $\begin{array}{c}\text { Concrete } \\
\text { compressive } \\
\text { strength } \\
{\left[\mathrm{N} / \mathrm{mm}^{2}\right]}\end{array}$ & $\begin{array}{c}\text { Yield strength } \\
\text { steel profile } \\
{\left[\mathrm{N} / \mathrm{mm}^{2}\right]}\end{array}$ & $\begin{array}{c}\text { Yield strength } \\
\text { reinforcement } \\
{[\mathrm{N} / \mathrm{mm} 2]}\end{array}$ \\
\hline 3 & 22.2 & 95.3 & 1930 & 30.9 & 373 & 479.2 \\
\hline 7 & 22.2 & 95.3 & 1930 & 62.9 & & \\
\hline
\end{tabular}

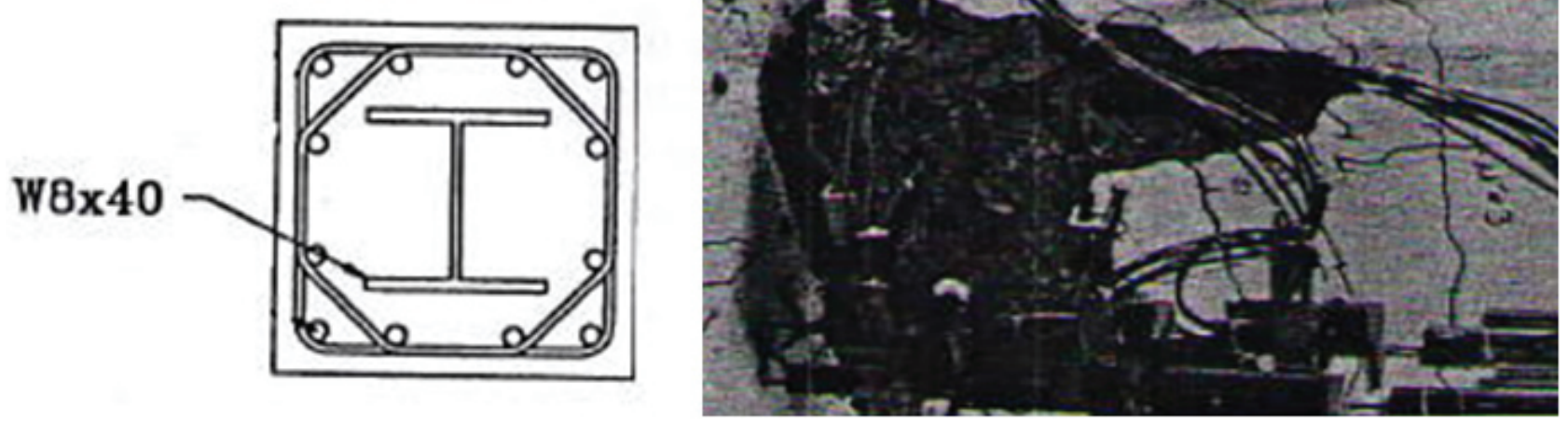

Figure 5: Cross-section of the tested specimens and failure mode 
Specimen 3 was made with normal concrete and specimen 7 with high strength con-cre 7 te (the compressive resistance is larger than $60 \mathrm{MPa}$ ). The cross-section of the tested co-lumns is presented in figure 5 and some characteristics regarding the specimens in Table 4.

The authors of the experimental tests performed only cyclic tests on the studied specimens. The failure of the tested specimens was similar to the other experimental studies presented (see Figure 5).

\section{EXPERIMENTAL PROGRAM DEVELOPED AT CTU, HSINCHU, CHINA, 2008}

The experimental program developed by Weng ChengChiang, Yin YenLiang, Wang JuiChen and Liang ChingYu, 2008, aimed the use of a multi- spiral cage of five interconnected spirals, named "5-spirals" as transversal reinforcement for rectangular columns. The tests were performed at the Department of Civil Engineering from Chiao Tung University, Hsinchu, China. All tested columns had the same cross-section, of $600 \mathrm{~mm} x$ $600 \mathrm{~mm}$ and the same height of $3250 \mathrm{~mm}$. The columns had a cross steel profile $2 \mathrm{H} 350 \times 175 \times 6 \times 9$ fully embedded in concrete (see Figure 6). The longitudinal reinforcement was the same, $16 \varnothing$ $25+4 \varnothing 13$. The diameter of the perimetral spiral was $\varnothing 13$ and for the four corner spirals $\varnothing 10$. The distances between the spirals were different, $95 \mathrm{~mm}$ for C-SRC1 column and $115 \mathrm{~mm}$ for the C-SRC2 column. The resistance of the materials were determined experimentally and are presented in Table 5.

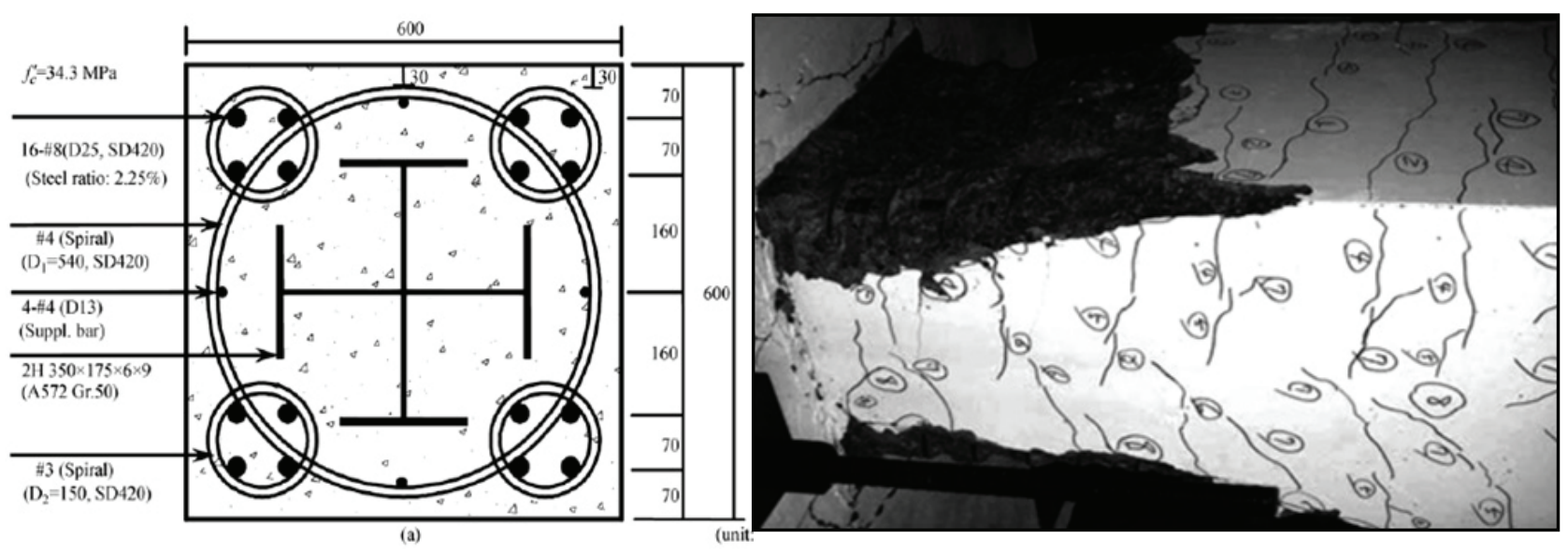

Figure 6: Cross-section of the tested specimens and failure mode

Table 5: Characteristics of tested specimens

\begin{tabular}{|c||c|c|}
\hline $\begin{array}{c}\text { Concrete compressive strength } \\
{\left[\mathrm{N} / \mathrm{mm}^{2}\right]}\end{array}$ & $\begin{array}{c}\text { Yield strength steel profile } \\
{\left[\mathrm{N} / \mathrm{mm}^{2}\right]}\end{array}$ & $\begin{array}{c}\text { Yield strength reinforcement } \\
{\left[\mathrm{N} / \mathrm{mm}^{2}\right]}\end{array}$ \\
\hline 37.3 & 435.3 & 437 \\
\hline
\end{tabular}

The tests ended when the drift angle of the composite column reached $6.0 \%$ radians. The concrete cover near the column base was tangibly flaked off, but the concrete confined by the 5spirals remain intact, the longitudinal reinforcement did not buckle, nor did the spirals break, as shown in figure 6.

\section{NUMERICAL MODEL FOR STEEL-CONCRETE COMPOSITE COLUMNS}

\section{Calibration and material laws}

The numerical model was developed in FineLg, a finite element program developed at ArGenCo department, University of Liège, Belgium. The proposed numerical model was calibrated against the five test results presented previously. The columns were considered as plane bars with 3 nodes (see figure 7 ). Node 1 and 3 has three degrees of freedom $(m, u, q)$. Node 2 has only one degree of freedom, which permits taken into account an eventual displacement between steel and concrete. In the analysis is considered a perfect connection between steel and concrete. The model uses multi-fibers beam elements with mono-axial nonlinear material laws for concrete, embedded steel and reinforcement steel (see figure 9). Because the validation of the numerical model was performed using experimental data, for the resistance of materials the safety coefficients were considered equal to 1 . 
The steel elements (embedded profile and longitudinal reinforcement) are defined using a bilinear law, presented in Figure 8a. The local and general bucking effects are not considered in the model. The buckling of the longitudinal reinforcement is prevented by the transversal confining reinforcement. A parabolic-rectangle law is used for concrete in compression (see figure 8c). The law takes into account the tension resistance of the concrete, which is evaluated with the SR EN 1992-1-1 formula.

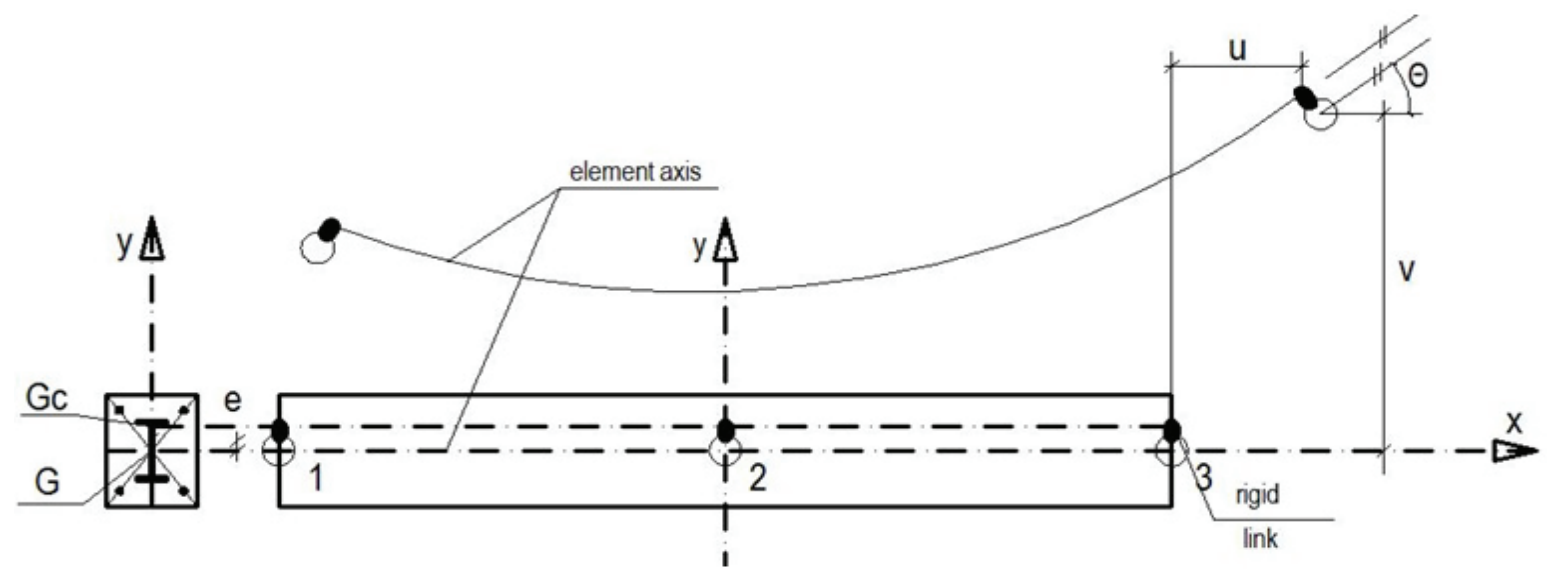

Figure 7: Finite element

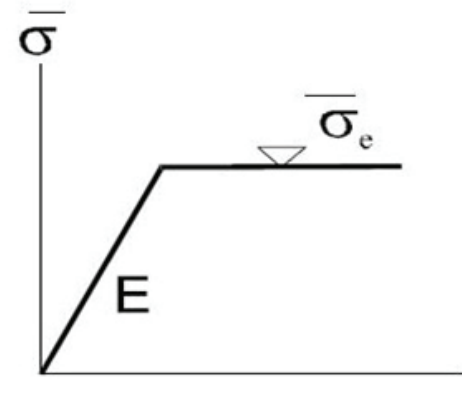

$\bar{\varepsilon} \mathrm{a}$
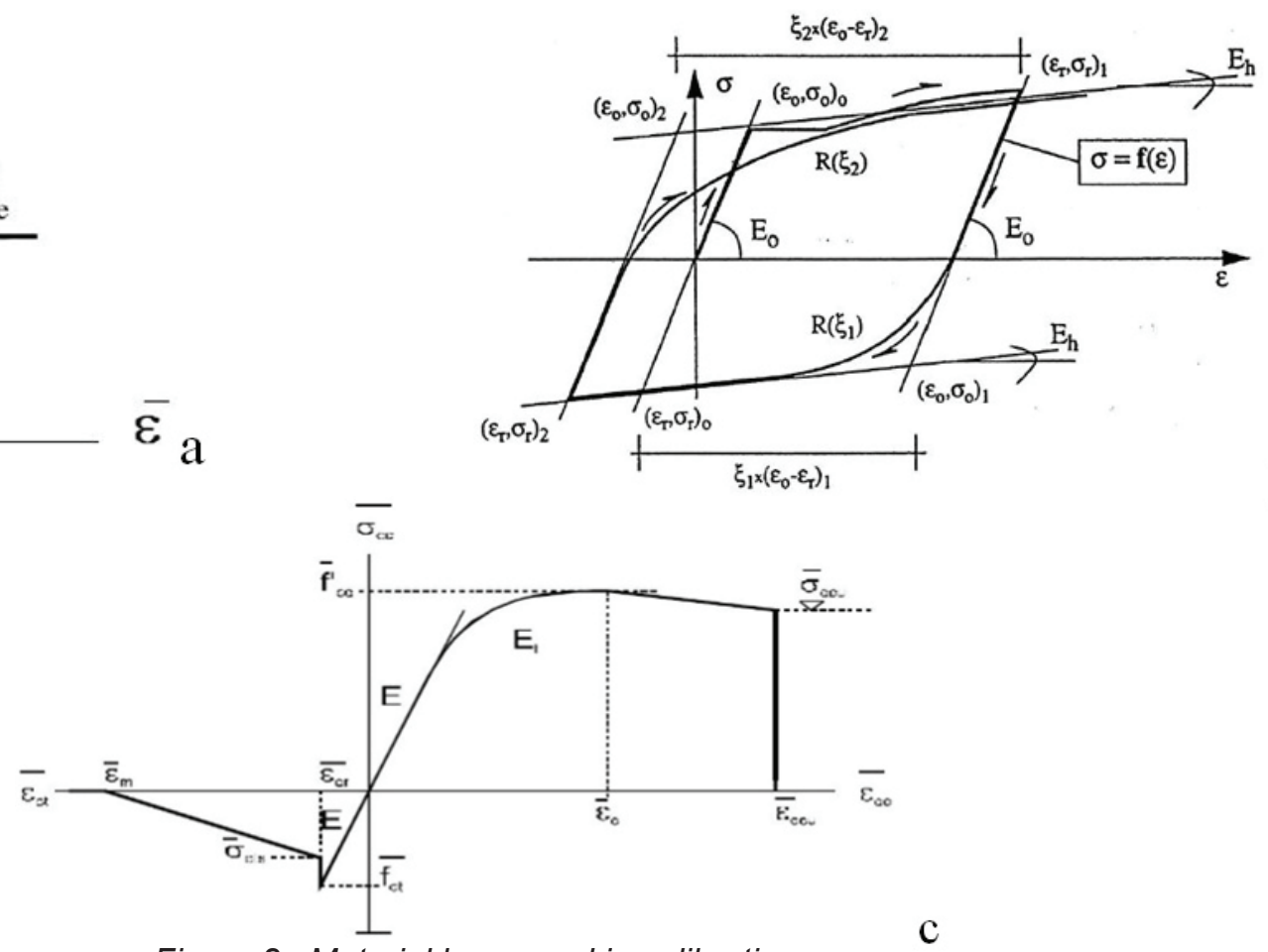

Figure 8: Material laws used in calibration
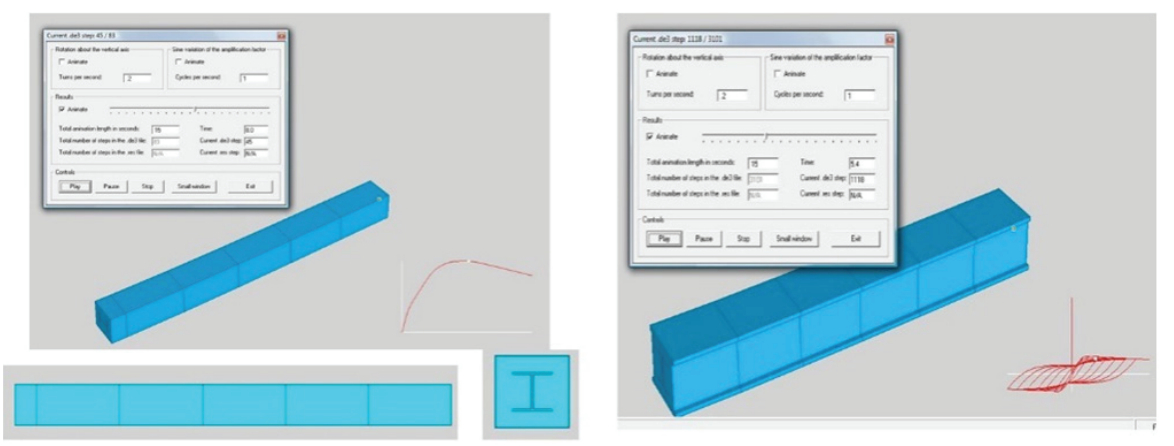

Figure 9: Calibration of monotonically and cyclically tested column 
The creep and shrinkage effects were not taken into consideration. In the model were used the confined values of the concrete. For normal concrete was used the SR EN 1992-1-1 law and for high strength concrete the Cusson-Paultre law. For simplicity the section was considered divided into two zones, confined (the zone between the transversal reinforcement) and unconfined (at the exterior of the transversal reinforcement). For the cyclic loading the Menegotto-Pinto law was used (see Figure 8b).

\section{VALIDATION OF THE NUMERICAL MODEL}

The validation of the numerical model is presented in figure 10, by comparing the force-displacement curves obtained experimentally and numerically. Figures $10 \mathrm{a}$ and $10 \mathrm{~b}$ present the results for the SIII column from the program presented at 2.1., tested monotonically and cyclically. Figures $10 \mathrm{c}$ and $10 \mathrm{~d}$ present the results
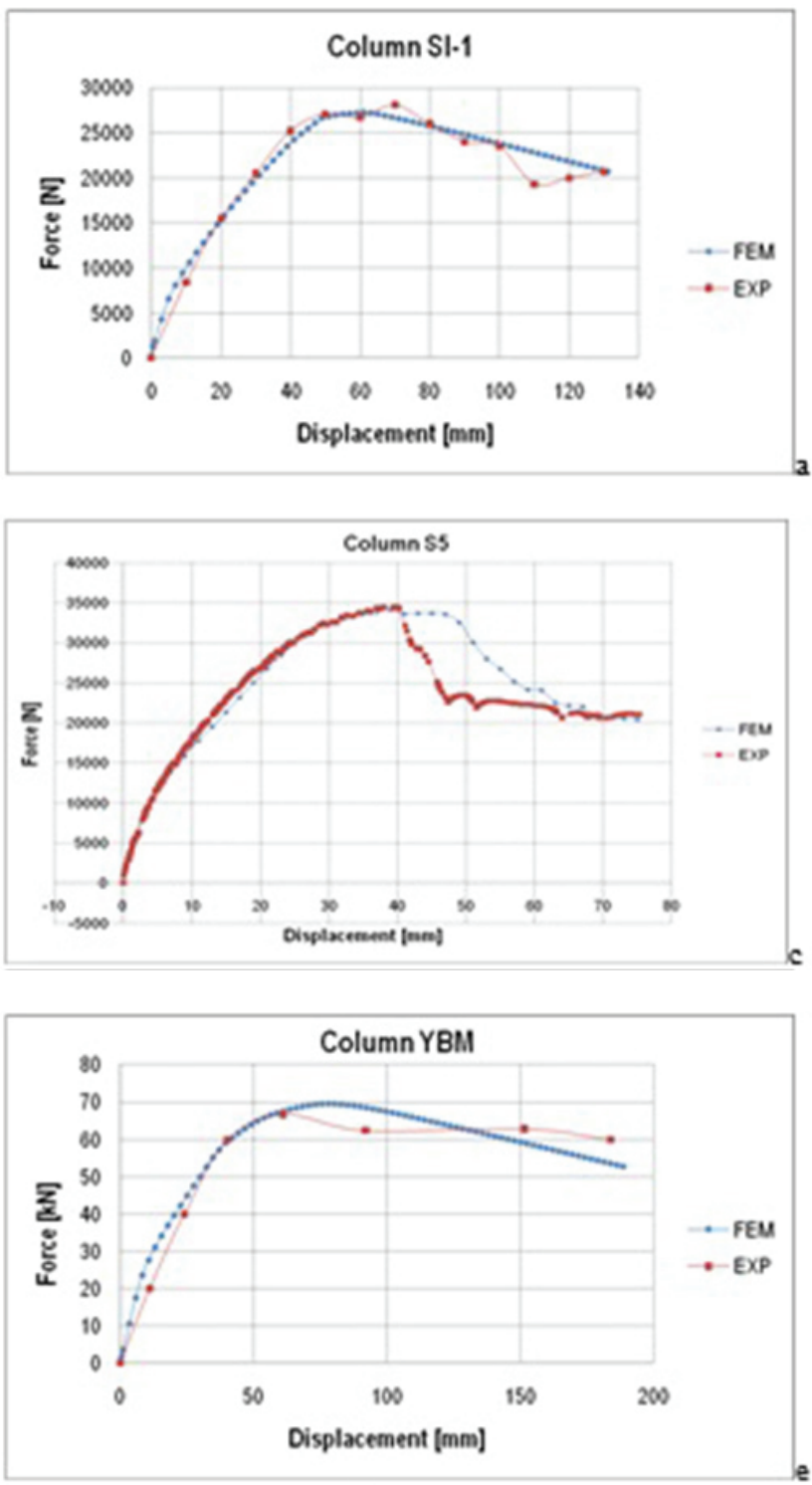

for the $2.00 \mathrm{~m}$ column made with high strength concrete from the Cluj-Napoca experimental program. Figures 10e and 10f present the comparison for YDM monotonically tested column and for XFCOO cyclically tested column from the experimental program developed in Taiwan. The experimental program developed in San Diego included only cyclic tests on columns made with both normal (see figure $10 \mathrm{~g}$ for specimen 3 ) and high strength concrete (see figure 10h for specimen 7). The validation of the numerical model for columns with cross profiles fully embedded in concrete is presented in figures $10 \mathrm{i}$ and $10 \mathrm{j}$. Until reaching the peak load the numerical model is quite accurate, the differences between the experimental and numerical values being under $5 \%$. After the peak load the numerical model doesn't offer such accurate results as before, the differences being about $15 \%$.
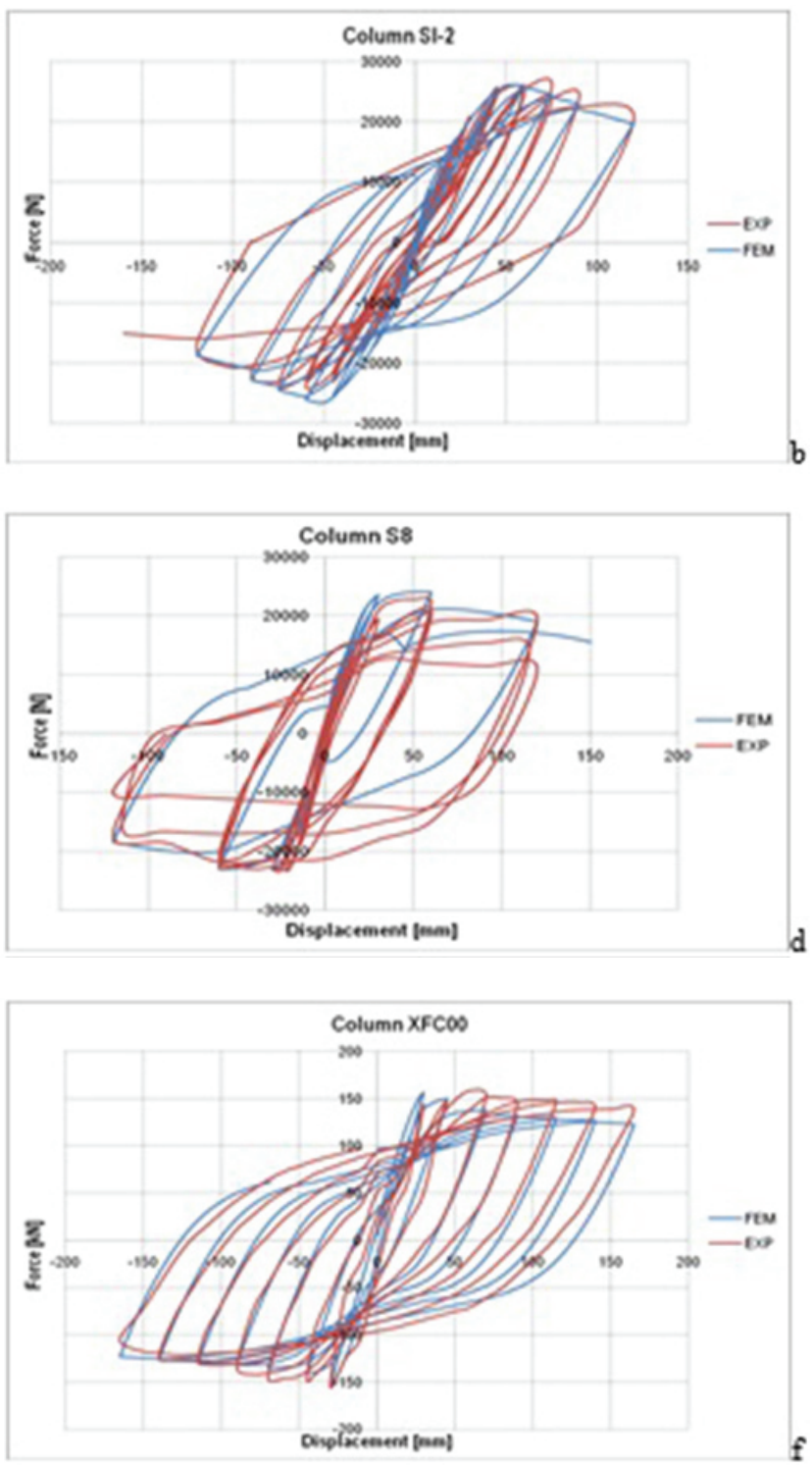

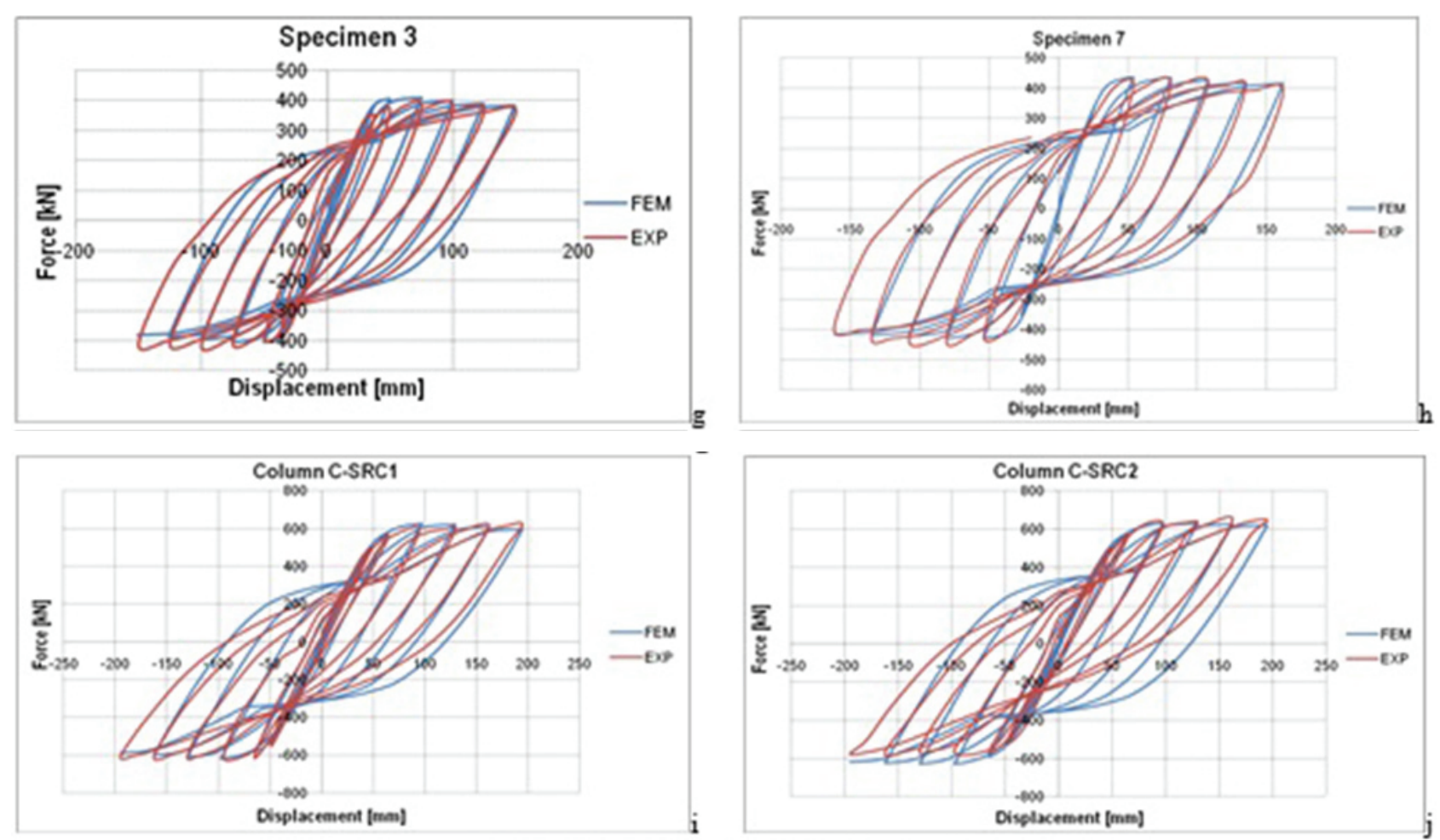

Figure 10: Validation of the numerical model

\section{CONCLUSION}

The solution of fully encased composite column is a competitive solution for seismic and nonseismic zones, due to the excellent seismic performances (resulted from the presented experimental tests) and also because of improved fire protection. The numerical modeling is a very efficient and economic investigation method for the behavior of fully encased steel-concrete composite columns, especially for sections that are not covered by the current provisions of the SR EN 1994-1-1, but cannot exclude experimental research. The results obtained on the columns made with high strength concrete showed improved performances, especially resistance. Due to the brittle fracture of the high strength concrete more experimental and numerical research must still be made.

\section{REFERENCES}

1) ASRO. SR EN 1992-1-1, Eurocod 2: Proiectarea structurilor de beton; Partea 1-1: Reguli generale și reguli pentru clădiri, lunie, 2006. Bucuresti: Asociaţia de standardizare din România (in Romanian).

2) ASRO. SR EN 1994-1-1, Eurocod 4: Proiectarea structurilor compozite de oțel și beton; Partea 1-1: Reguli generale și reguli pentru clădiri, Mai, 2006. Bucuresti: Asociaţia de standardizare din România (in Romanian).

3) Câmpian Cristina. Contribution a l'etude du comportament et au calcul de poteaux mixtes acier-beton (sous des charges transversales de variation monotone ou cyclique alternee), Teză de doctorat, INSA Rennes, 2001.

4) Cusson D., Paultre P. Prediction of effective confinement pressure in high-strength concrete columns, CSCE 2008 Annual Conference Structural Specialty, Quebec City, QC., June 10-13 2008, pp. 10.

5) ECCS (1986): Recommended testing procedure for assessing the behaviour of structural steel elements under cyclic loads, Doc. no 45 of European Convention for Constructional Steelwork, TWG 1.3, 1986.

6) FineLg User's manual, V9.0 (2004) - University of Liège (M\&S)/Design office Greisch (BEG)

7) Hsu H-L, Jan F., Juang J-L. Performance of composite members subjected to axial an biaxial bending, Journal of Constructional Research 65, 869-878, 2009.

8) Sav Vlăduț. Stâlpi cu secțiune mixtă oțel-beton folosind beton de înaltă rezistență, Teză de doctorat, Cluj Napoca, 2011.

Paper sent to revision: 07.02.2014.

Paper ready for publication: 15.03.2014. 